\title{
The Readiness of Radio Stations to Deal with Disruptive Digital 2020
}

\author{
Endang Setiowati* \\ Broadcasting Laboratory, Vocational Education Program, Universitas Indonesia
}

*Email: endang.setiowati@ vokasi.ui.ac.id

\begin{abstract}
As the digitalization of broadcasting allows for the efficient use of the limited number of frequency channels, many players are able to join the broadcast industry. While many countries have had digital broadcasting for many years, Indonesia will only implement it in 2020. Broadcast migration from analog to digital is expected to have a significant impact on the broadcast industry as it shifts to digital, which has been termed disruptive digital, with the major obstacles being technology and content. Using observation and an in-depth interview with the head of technical development at the National Private Radio Association of Indonesia (PRSSNI), this research examined the readiness of the main radio industry in Indonesia to move to the digital era in 2020s. It was found that while PRSSNI members were ready to deliver digital broadcasting content, government collaboration was needed to ensure adequate development of the technological infrastructure.
\end{abstract}

Keywords: disruptive digital, $D A B+$, single mux, multi mux

\section{Introduction}

The European Broadcasting Union (EBU) in their vision book 2020 claimed that the most significant issues for the broadcasting industry were internet development, digitalization, globalization, and demographic changes. Internet developments have allowed for increases in gadget usage and an expansion of audio visual over the top (OTT) content, which is the delivery of audio, video, and other media content over the Internet without the involvement of a multiple-system operator; however, Indonesia currently faces problems such as a lack of OTT organizational arrangements and poor user protection against cyber content. Digital development focuses on technological change, spectrum source efficiency, improved acceptability, and local content optimization. Globalization involves the entry of broadcast stations from all over the world into Indonesia, which is expected to significantly increase competition for both the Broadcasting Institution and private institutions. The World Bank reported that in 2010, $46 \%$ of people lived in rural areas and 54\% lived in urban areas and projected that by 2050 , rural populations would decline to $33 \%$ and urban populations would increase to $67 \%$, which means that more diverse broadcast content would be needed https://www.ebu.ch/files/live/sites/ebu/files/Publications/EBU-VISION2020_Strategy_EN.pdf).

When digital broadcasting is introduced in 2020 in Indonesia, it is expected that there will need to be some convergence of analog TV and radio and digital internet based TV and Radio to allow for the live internet streaming of radio and TV; that is, the telecommunications industry will need to encompass broadcasting, digital economic transactions, and information under one institution so that various facilities, such as Voice Over the Internet protocols (VoIP), ViCon, VoD, rich communication Internet Broadcasting, email, e-tracking, e-logistic, OTT, and IoT, can be actioned (https://www.slideshare.net/ery_lutfi/paparan-landscape-industri-penyiaran-5sept2017-rev3). It is expected that all analog broadcasting industries will open digital channels, and to fulfill the needs of various audience segments, changes will be needed in the media content to cover local, national, and global content t. Broadcast and CableSat, 2017)

In 2012, European broadcasters researched the adaptations and institutional convergences needed in the public service media broadcast industry to provide these new complex services, and found that network members needed to work together to determine the communication strategies to meet the audience needs (Bierman).

Research on the digital transition of Korean TV stations tracked the interactions between social entities and technology from different perspectives at different stages of the development to examine the dynamic 
stakeholder interactions during the transition. It was found that the actions of the key stakeholders significantly influenced the actions of the different stakeholder groups and that the transition to digital TV was the result of a proactive strategy by industry stakeholders and supportive top-down policies of the Korean government. However, this top-down transition policy tended to ignore stakeholder coordination, which was found to harm consumers and hamper effective and sustainable development. Therefore, the Korean case has been widely cited as an example of what not to do for other countries undergoing digital transition (Shin \& Song, 2012).

China, in its the transition from analog to digital TV, adopted a "uniform transition" policy in which the network operators gave each urban household a set-top box (STB) for free provided that they would subscribe to their digital services for a certain period, which was usually 1 or 2 years. Except for the retention of six dedicated analog channels, when most of the population had switched to digital, the analog TV signal was turned off. Because of the" uniform transition" policy and because many people feared that they would only have six channels to watch, most transitioned to digital TV (Wan, Hu, \& Wu, 2009).

The European Commission identified four essential criteria for ideal next generation network infrastructure technological convergence: (1) an open system, (2) layered architecture, (3) digital signal processing, and (4) platform independence (that is, correct connectivity and interoperability). An "open system" has public-defined protocols that offer a suitable scale and scope to achieve profit in the market, which is different from a "closed system" or a proprietary system that secures private advantage and may limit market access. Layered architecture binds various parts of the information infrastructure, such as digital signal processing and platform independence, to allow for convergence that supports connectivity and interoperability. The philosophy of layered architecture models is that as each layer is relatively independent of the other layers, there are a myriad of development possibilities (Shin, 2006).

Halbert from the University of Miami identified five major factors that could inhibit the growth of digital radio or HD Radio in the United States: (a) the emergence of other digital audio technologies, (b) the launching and marketing of unplanned products, (c) small investment earnings for broadcasters, (d) sluggish programming and other related content, and (e) an overall economic slowdown in the radio industry. Halbert also examined the degree of diffusion in existing radio industry social systems and found that while diffusion had occurred entirely through the regulatory systems, diffusion had been significantly impeded because of listener and radio industry impediments. For example, radio stations that had switched to HD were experiencing a standstill because their return on the investment into HD broadcasting technology was not reflected in their ratings or revenue. It was also found that consumers were not actively purchasing the required technology to listen to digital broadcasts primarily because they had little knowledge of the technical differences between HD Radio and satellite radio. While HD Radio was integrated into cars and many manufacturers had developed compatible and embedded devices in car radio receivers, the consumer diffusion of these technological developments was lacking. (Halbert, 2015).

In Indonesia the analog to digital switching system problems are mainly related to frequency management and digital infrastructure; that is, whether there should be a single multiplexor (mux) system held by one institution such as TVRI, which would join with RRI to form the Public Broadcasting Institution Radio Televisi Republik Indonesia (LPP RTRI), or whether there should be a multi-multiplexor (mux) system in which frequency management would be controlled by several OTT media services and in which the private broadcasters would manage their own frequency and digital infrastructure developments. There have also been proposals focused on a hybrid system in which the private OTT media services would control one frequency and as each frequency can support up to eight channels, any surplus frequencies must be made publicly available. (Damarjati)

However, these single mux and multi mux decisions only exist for digital television services. The transition to digital radio is more concerned with technological and content readiness, primarily because a majority of radio stations are single, non-networked or syndicated, and therefore, to some degree unprofessional. What this means, however, is that the transition to digital radio is going to significantly change the shape of the industry (https://news.detik.com/kolom/d-3521935/menatap-rencana-undang-undang-penyiaran-yang-baru-harapan-atauketidakpastian).

Disruptive digital technological issues are a concern for both the media and their potential listeners because to enjoy digital broadcasting they must buy a receiver device called a set-top box (STP). Therefore, people must be willing to purchase additional devices to receive digital radio broadcasts.

In Indonesia, therefore, there are some disruptive digital broadcasting problems, particularly in the radio industry, in terms of the provision of content, institutional broadcasting, and infrastructure organization. This research examined the readiness of the Indonesian radio industry in overcoming these digital broadcasting transition problems. 


\section{Literature Review}

The terms disruptive and discontinuous innovations were coined after Christensen published "The Innovator's Dilemma" in 1997. Disruption was seen as a stronger and more tangible qualification than discontinuous as it offered a better explanation; however, the events discussed under disruptive and discontinuous innovations were seen to be very similar (Kilkki et al., 2018).

Cambridge Dictionaries Online (2017) gives the following definition for disruption; to prevent something, especially a system, process, or event, from continuing as usual or as expected. An agent, when pursuing some predefined goals, makes intentional decisions and performs some actions that in turn affect other entities. As sometimes the effects are either intentionally or unintentionally disruptive, a disruptor is an agent that disrupts the functioning of some other agents, who are called disruptees. Therefore, from the disruptive perspective, an agent can be a disruptor, a disrupted, or a neutral actor (Kilkki et al., 2018).

To change a company's value generation model, digital disruption typically require employees to gain new skills, which inevitably causes pressure. Disruption also occurs when established technologies are adopted by new business sectors or because of innovative combinations of two or more old technologies. The effects of these disruptions can have a range of effects on the technology, the business model, and the consumers. For example, a disruptive new technology can affect the company's value generation model and allow them to offer new products. However, not all new products that pass through the industry layer have a direct disruptive effect on the industrial architecture (Kilkki et al., 2018). If there is a significant consumer demand for the new products, the technological impulse can turn into a market appeal, which means that the disruption can significantly affect the whole industry as well as individual company layers. For example, when the short messaging service (SMS) technology emerged, consumer adoption was much faster than had been expected by the service provider, which indicated that there was an consumer desire for online social interactions, which then led to the emergence of social media applications (Hillebrand et al., 2010).

Since the mid-1990s, there has been a strong focus on the move to digital radio broadcasts as it was seen that radio could transform significantly in the future because of the development of a new digital broadcasting technology, called Digital Audio Broadcasting (DAB), that offered superior engineering quality, better audio reception, the possibility of integrating data and multimedia content, and higher overall efficiency. The most established DAB system, Eureka-147, was developed in Europe as a standard in the mid-1980s and was also tested extensively and then adopted by Canada in the early 1990s (O'Neill, 2007).

The radio industry agrees that digitalization through DAB is a key goal for radio industry development. However, even though the technical superiority of digital radio broadcasting has been widely demonstrated, its feasibility and prospects remain uncertain as the DAB development pattern for international radio broadcasting has varied considerably. While some countries such as the United Kingdom have successfully promoted DAB, some countries in Europe have delayed implementation while other countries are implementing it earlier. About ten years after the start of the DAB, its international implementation has been somewhat patchy, with broadcasters and regulators continuing to evaluate other approaches to realize a fully efficient digital radio landscape (O’Neill, 2007).

\section{Digitalization in Radio Stations in Indonesian}

There are several reasons that radio stations should go digital from both government and technological perspectives. From the Government side, because the available non-digital channels are limited, they are unable to deal with the many radio channel requests, and for the LPP RRI, which has been conducting DAB + test in 12D VHF channel (229.027 MHz) since 2012, digital radio would provide the future capital to allow them to become the main "multiplexing" players. From the technological side, as one digital channel can relay four times the content than analog, there would be a significant increase in channel efficiency (see Figure 1) in terms of infrastructure and power usage as $\mathrm{DAB}+$ electric power is only 1/8 that of analog (see Figure 2). Further, the audio quality is equivalent to a $\mathrm{CD}$, there is no interference from issues such as the weather, and as digital radio is centralized, it is easier to control (Sutama, 2018). 


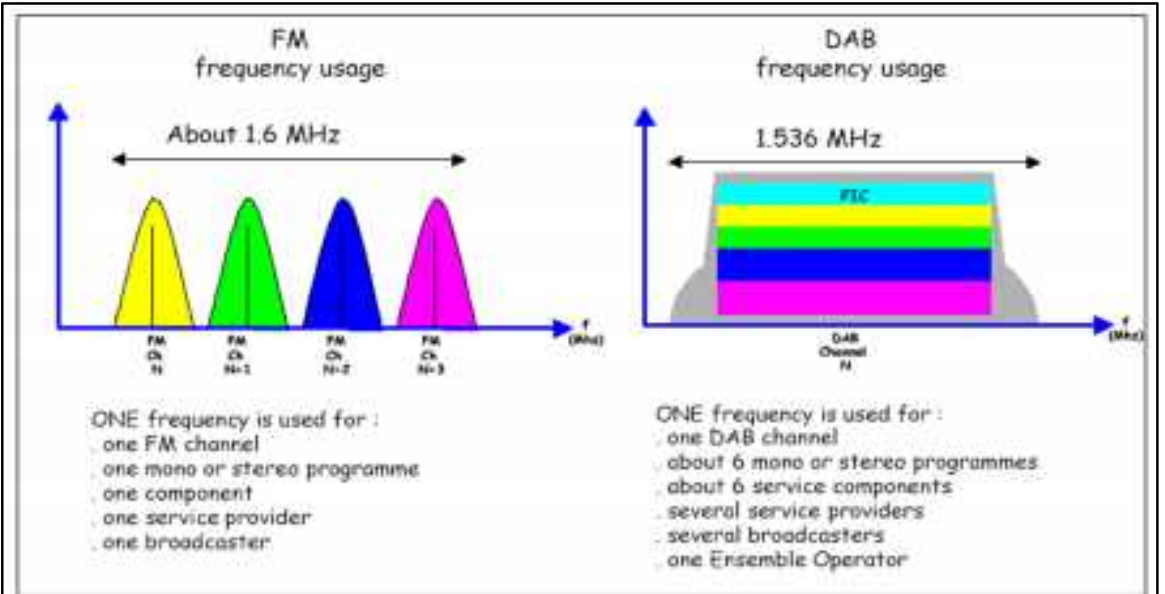

Figure 1 FM vs DAB frequency usage



Figure 2 Efficient Infrastructure

The DAB+ system is to be implemented in Indonesia on the III VHF 174-216 MHz band frequency. As one channel III VHF $7 \mathrm{MHz}$ band can be divided into four sub-channels, each sub-channel can accommodate 16 broadcast programs; therefore, 1 VHF channel can offer 64 broadcast programs.

Because China is producing receivers that are less than $\$ 30 \mathrm{US}$, it is expected that DAB receiver penetration will be relatively rapid in Indonesia. As the manager of the future multiplex system, RRI has been very active in conducting workshops and trials on channel $12 \mathrm{D}$, and while the determination of the digital radio standard has been done in Indonesia for DAB on the III VHF 174-216 MHz band, the regulations for and the masterplan to manage the canal allocations have not yet been developed (Sutama, 2018).

The separation between the content providers and the infrastructure providers will require significant investment by the broadcast industry; therefore, the entity/consortium is required to ensure that the $D A B$ Network Provider infrastructure that is built is focused on the common good (Sutama, 2018).

If the DAB+ deployment is not implemented correctly, it could be a threat to FM broadcasting because: (1) DAB operates on the same platform as FM radio (terrestrial VHF) and is FTA (Free to Air); (2) even through $\mathrm{DAB}+$ has several advantages, the quality and coverage are the same; (3) every city in Indonesia will have at least 64 new FM radio programs, which may saturate the market; (4) if the mux player is only the LPP as mandated in Radio and Television bill (UU RTRI), then there could be uncontrolled monopolistic practices (Sutama, 2018).

\section{Methodology}

To collect the data for this research, a qualitative approach was applied using in-depth interviews and observation. The in-depth interview allow for information to be obtained through focused questions and answers in a relatively long communication. There are three kinds of observation: controlled observation, participant observation, and natural observation. In this research, natural observations were conducted, which involved 
studying the spontaneous behavior of the participants in their natural surroundings with the researcher simply recording what they saw (Bryman, 2012).

One informant was interviewed for this research; Agus F.I Sutama, the manager of the Technical Department of the Indonesian National Private Radio Association (PRSSNI) and also the Head of Engineering at PT MARI Tbk (Mahaka Radio Integra), a company group that owns six radio stations. PT MARI Tbk is also the member of the MAHAKA Group, a radio, television, and newspaper group.

\section{Results and Discussion}

The Ministerial Regulation of Communication and Information (Permen Kominfo) no. 21/PER/M.KOMINFO/4/2009, which references the Digital Broadcasting Standard for VHF frequency band in Indonesia for the DAB Family (Digital Audio Broadcasting Family), outlines the regulatory framework for the digitalization of Indonesian broadcasting in 2020 for all private radio stations that are members of the Indonesian National Private Broadcasting Association (PRSSNI). The Digital Broadcasting Standard for the Frequency Medium Frequency band in Indonesia is planned to be DRM 30.

Technically, private broadcast radio has few rules; however, the DAB technological system allows for greater efficiency as its audio quality is equivalent to that of FM radio and a digital CD. While it is expected that the DAB radio receivers will be embedded with an existing FM tuner, the most important consideration for the business model is to avoid market saturation or channel management monopolization. As stated by an informant,

Secara teknologi tidak ada kendala buat anggota PRSSNI, broadcaster akan semakin efesien secara teknologi yg harus diatur adalah model bisnis dan aturan skema deploymen DAB disuatu daerah karena pada setiap radio penerima DAB selalu diembeded/disatukan dng tuner FM, karena kualitas audio DAB menyamai kualitas audio FM maka DAB adalah "extended FM Channel" sehingga DAB bisa menjadi kompetitor baru bagi FM, apabila deployment DAB tidak dikontrol dengan baik maka akan terjadi persaingan bisnis yg tidak sehat.

The monopolization of channel management has been seen as a problem for both digital television and radio. In a DAB system, the channel management uses a multiplexer system or MUX. Single Mux refers to a single designated operator controlling the channel allocation management; in this case, the Public Broadcasting Institution Radio and Television (LPP RTVI); and multi mux is when the channel management is allocated to several companies. The broadcasting industry, and especially the television industry, felt that single mux would lead to broadcast control by the Director General of Radio and Television, but it there were a multi mux system, there could be uneven competition against those companies that do not have channel allocation authority as large companies with channel allocation authority would be able to grow, but smaller companies would find it difficult to reach the market because they were allocated unfavorable channels.

As stated by the informant, the single mux system, however, is considered most ideal for radio, with RRI being the single mux regulator, as the broadcasting would be more efficient, and unbalanced competition could be avoided.

Radio Digital dalam sistim DAB menggunakan mux (multiplexer) yg dapat menampung $8 \mathrm{~s} / \mathrm{d} 32$ konten per-mux, idealnya DAB menggunakan single mux dengan keuntungan sbb: Persiaran lebih efesien, mudah dikontrol/regulator memiliki akses penuh kepada mux, kompetisi antar penyelenggara akan lebih sehat dll dibanding menggunakan multi mux.

One of the main advantages of DAB deployment is the separation between mux organizers and the content providers, which also allows private radio station PRSSNI members to collaborate with other entities such as RRI, state-owned enterprises (BUMN), and the local government to build mux funded or operated consortiums, which means that financing, technology, human resources etc. may not be constraints. As stated by the informant, the important issue is that the system monetization be calculated from the overall DAB deployment.

Judging from the readiness of the content, private radio does not foresee any constraints because the content is relatively similar to the content on analog radio. Moreover, private radio is already familiar with the production of creative and varied content. As stated by informant,

DAB adalah suatu system audio konten servicing, PRSSNI merupakan asosiasi radio yang berbisnis di system audio konten servicing Pertama, terbanyak anggotanya dan tertua, sehingga mungkin tidak ada kendala dalam penyiapan konten. 
The concern of private radio stations is the development of business model rules that allow the radio industry to continue to grow. Therefore, the PRSSNI has proposed a business model to the government to ready the radio industry for the disruptive digital effects. As described by the informant, (see Figure 3)

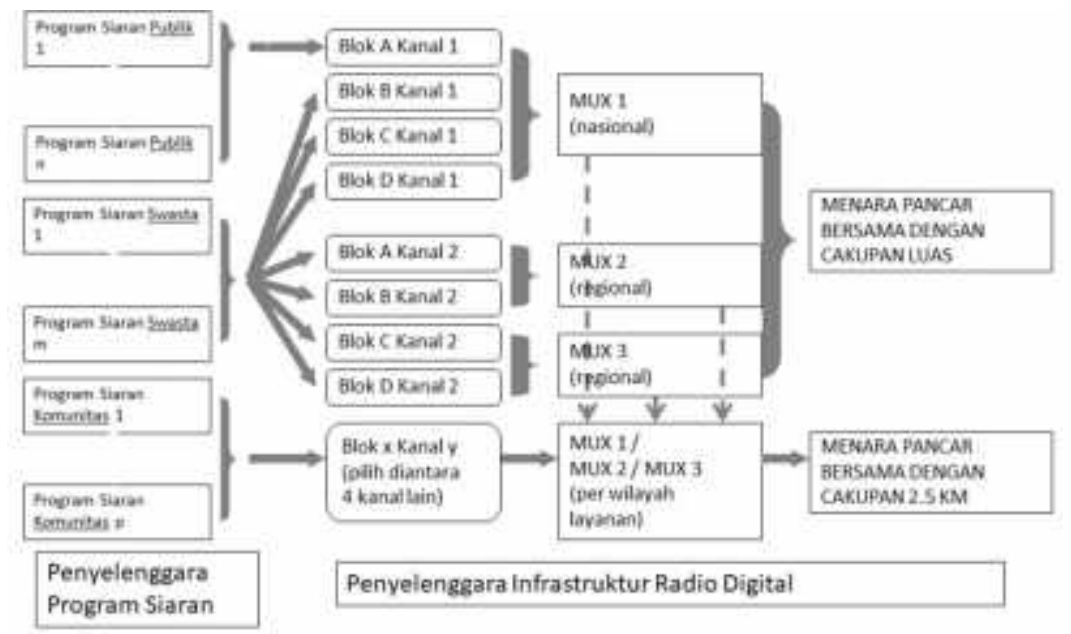

Figure 3 Business Model Proposed by PRSSNI

Figure 3 shows that ideally every Broadcasting Institution, whether Public, Private, or Community based, is their own content organizer, and occupies the channels specified by each mux organizer, with the mux consisting of local, national, and regional mux. The infrastructure procurement will be managed by a MUX collaboration between RRI, BUMN, and the local government, which will make it easier for the radio stations to switch to digital broadcasting and prevent monopoly and unhealthy competition.

Another obstacle or constraint is the audience. Although the DAB system will be embedded into FM tuners, the device will be quite expensive at about 30 USD or around IDR 420,000, and if audiences have to also buy a STB for their televisions, they will possibly choose to buy the TV device rather than the radio device. As mentioned in the introduction, in other countries, the government helped people buy both the STB for the TV and the shifting device for radio to allow for an easy move from analog to digital. However, in Indonesia, it is still unsure as to whether the government will assist people to move from analog radio to digital.

\section{Conclusion}

While the radio industry is well prepared to shift to the digital age, there are still concerns about radio business saturation and the procedures needed to assist audiences to enjoy digital broadcasting.

However, the move to digital broadcasting should not be delayed as it is the best solution to overcome the inefficiencies associated with current analog broadcasting. To avoid disruptions to the radio broadcasting industry, digital radio needs to be correctly deployed; that is, full consideration is needed of all aspects.

In contrast to the migration to digital $\mathrm{TV}$, digital radio is planned to be a supplement to existing systems as the DAB is to be allocated on new channels (band III TV $174 \mathrm{MHz}-220 \mathrm{MHz}$ ) with FM Radio remaining on 87 $\mathrm{MHz}-108 \mathrm{MHz}$. However, when the DAB receiver price lowers to around 10USD, there would be a higher penetration, which would result in significant competition between DAB stations and FM stations. As all stations will share infrastructure, it is expected that unhealthy technical coverage and audio quality competition can be avoided.

\section{References}

Bierman, R. "Vision 2020: An E B U Project Connecting to A Network Society," Ruurd Bierman media features [Online]. Retrieved from http://www.ruurdbierman.com/projects/vision-2020-an-ebu-project/.

$\begin{array}{lllll}\text { Broadcast and } & \text { CableSat. } & \text { (2017) } & \text { Retrieved }\end{array}$ https://search.proquest.com/docview/1867934387? accountid=17242.

Bryman, A. (2012). Social research methods (4th ed). New York: Oxford University Press.

Cambridge dictionaries online. (2017). [Online]. Retrieved from http://dictionary.cambridge.org/. 
Damarjati, D. "Multi Mux vs Single Mux di RUU Penyiaran, Baleg DPR: Masih Deadlock," detiknews, 23 January 2018. [Online]. Available: https://news.detik.com/berita/3830163/multi-mux-vs-single-mux-diruu-penyiaran-baleg-dpr-masih-deadlock. [Accessed 25 April 2018].

Halbert, J. C. (2015). A case study of HD Radio diffusion in the United States. Miami: University of Miami.

Hillebrand, F., Trosby, F., Holley, K., Harris, I., \& Short Message Service (2010). The creation of personal global text messaging, John Wiley and Sons, Ltd. doi: 10.1002/9780470689899.

Kilkki, K., Mäntylä, M., Karhu, K., Hämmäinen, H., \& Ailisto, H. (2018). A disruption framework. Technological Forecasting and Social Change, 129, 275-284. doi: 10.1016/j.techfore.2017.09.034.

O'Neill, B. (2007). Digital audio broadcasting in Canada: Technology and policy in the transition to digital radio. Canadian Journal of Communication, 32(1), 71-90. doi: 10.22230/cjc.2007v32n1a1809.

Shin, D. H. (2006). Socio-technical challenges in the development of digital multimedia broadcasting: A survey of Korean mobile television development. Technological Forecasting and Social Change, 73(9), 11441160. doi: 10.1016/j.techfore.2005.11.004.

Shin, D., \& Song, H. (2012). The switchover to digital broadcasting in Korea. Technological Forecasting and Social Change, 79(8), 1447-1461. doi: 10.1016/j.techfore.2012.04.017.

Sutama, A. F. (2018). Writer, Tinjauan Radio Digital DAB+ Pelatihan Pengukuran Radio Siaran - Wisma PPSDM Ditjen SDPPI, 26 April 2018, Cidokom Puncak-Jawa Barat. [Performance]. Persatuan Radio Siaran Swasta Nasional Indonesia (PRSSNI).

Wan, X., Hu, H., \& Wu, C. (2009). A theoretical and empirical study on China's transition to digital TV. Telecommunications Policy, 33, 653-663. doi: 10.1016/j.telpol.2009.08.001.

I. SK, "DetikNews," Menatap Rencana Undang-Undang Penyiaran yang Baru, Harapan atau Ketidakpastian?, 6 June 2017. [Online]. Available: https://news.detik.com/kolom/d-3521935/menatap-rencana-undangundang-penyiaran-yang-baru-harapan-atau-ketidakpastian. [Accessed 17 May 2018].

E. O. E. V. a (2014). VISION2020: Involevem inspirem and innovate. Eur. Radiol. [Online]. Retrieved from https://www.ebu.ch/files/live/sites/ebu/files/Publications/EBU-VISION2020_Strategy_EN.pdf.

K.K. d [Online]. Retrieved from https://www.slideshare.net/ery_lutfi/paparan-landscape-industri-penyiaran-5sept2017-rev3. KOMINFO, "Landscape Industri Penyiaran Indonesia 2017 - 2020," 5 September 2017 p. I. 